\title{
METODE DAN MODEL DALAM DOKUMENTASI ASUHAN KEPERAWATAN
}

\author{
Miranda Sipayung \\ @miranda.sipayung068@gmail.com
}

\section{Latar Belakang}

Dokumentasi Asuhan Keperawatan merupakan informasi tertulis tentang status dan perkembangan kondisi klien serta semua kegiatan asuhan keperawatan yang dilakukan oleh perawat. Dokumentasi keperawatan dalam bentuk dokumen asuhan keperawatan merupakan salah satu alat pembuktian atas tindakan perawat selama menjalankan tugas pelayanan keperawatan.

Dokumentasi keperawatan merupakan suatu yang mutlak harus ada untuk perkembangan keperawatan khususnya proses profesionalisasi keperawatan serta mempertahankan keperawatan sebagai suatu profesi yang luhur dan terpandang di masyarakat. Dokumentasi keperawatan dalam bentuk dokumen asuhan keperawatan merupakan salah satu alat pembuktian atas tindakan perawat selama menjalankan tugas pelayanan keperawatan.

Dokumentasi keperawatan mempunyai makna penting dalam aspek hukum, kualitas pelayanan, komunikasi, pendidikan, penelitian, dan akreditasi. Berkaitan dengan perlindungan hukum, dokumentasi asuhan keperawatan dapat memberi bukti yang berharga tentang kondisi pasien dan pengobatannya dan dapat bersifat kritis dalam menentukan standar perawatan apakah telah dipenuhi atau tidak.

Dokumentasi keperawatan adalah rangkaian kegiatan yang dilakukan oleh perawat, berkaitan dengan pencatatan dan penyimpanan informasi yang lengkap dan benar, tentang keadaan pasien selama dirawat. Kegiatan konsep pendokumentasian meliputi ketrampilan berkomunikasi, ketrampilan pendokumentasian proses keperawatan, dan ketrampilan standart.Penelitian ini dilakukan dengan cara mengambil seluruh sampel status pasien atau rekam medis pasien. 


\section{Metode}

Metode ini di gunakan untuk meingkatkan dan mencapai suatu tujuan dalam penelitian ini yang di ambil atau bersumber dari berbagai jurnal - jurnal. Cara pengumpulan data menggunakan berbagai media pendukung seperi handphone dan laptop dengan adanya data internet mempermudah penelusuran berbagai junal penelitian dari google..Pada penelitian ini metode yang dikumpulkan mengenai metode dan model dalam dokumentasi

\section{Hasil}

Hasil penelitian ini di ambil dari berbagai sumber jurnal, mulai dari Ardenny dan Hirzal. 2016. Efektivitas format pendokumentasian keperawatan model problem oriented record ( POR ) terhadap kemudahan penggunaanya oleh perawat di rawat inap jalan RSUD petala bumi pekanbaru. Wulandari. Dyah fitri dan Hanny Handiyani. Pengembangan dokumentasi Keperawatan berbasis elektronik di rs x kota depok dengan menggunakan teori perubahan lewins. Jurnal Keperawatan Global, Gustomi, Mono Pratiko dan Churin'in. 2015. Penerapan model dokumentasi asuhan keperawatan Problem Oriented Record (POR) Terhadap kinerja perawat (Effect of Problem Oriented Record (POR) Nursing Documentation Model on the Performance of Nurses). Astuti, neneng, dkk. 2010. Analisis kelengkapan pendokumentasian asuhan keperawatan pasien di rawat inaprumah sakit tampan pekan baru. Sugiyati, Sri. 2015. Hubungan Pengetahuan Perawat Dalam Dokumentasi Keperawatan Dsengan Pelaksananya Di Rawat Inap RSI Kendal,dll.

Dokumentasi keperawatan sangat penting bagi perawat dalam memberikan asuhan keperawatan.Dokumentasi ini penting karena pelayanan keperawatan yang diberikan pada klien membutuhkan catatan dan pelaporan yang dapat digunakan sebagai tanggung jawab dan tanggung gugat dari berbagai kemungkinan masalah yang dialami klien baik masalah kepuasan maupun ketidakpuasan terhadap pelayanan yang diberikan.(Hidayat, 2001). Perawat bertanggung jawab dan bertanggung gugat dalam pencatatan tindakan keperawatan. Tanpa dokumentasi yang benar dan jelas, kegiatan pelayanan keperawatan yang telah dilaksanakan oleh seorang perawat tidak dapat dipertanggungjawabkan dalam upaya peningkatan mutu pelayanan keperawatan dan perbaikan status kesehatan klien. Beberapa hal yang sering menjadi alasan antara lain banyak kegiatan-kegiatan di luar tanggung jawab perawat menjadi beban dan harus dikerjakan oleh tim keperawatan, sistem pencatatan yang diajarkan terlalu sulit dan banyak menyita waktu, tidak semua tenaga perawat yang ada di institusi pelayanan memiliki pengetahuan dan kemampuan yang sama untuk membuat dokumentasi keperawatan sesuai 
standar yang ditetapkan dan dikembangkan oleh tim pendidikan keperawatan sehingga mereka tidak mau membuatnya (Arikh, 2011).

\section{Pembahasan}

\section{Dokumentasi Asuhan Keperawatan}

Hasil penelitian menunjukkan bahwa pendokumentasian dalam metode dan model keperawatan setiap catatan baik tertulis maupun elektronik yang menggambarkan layanan keperawatan yang diberikan kepada klien dan dapat digunakan sebagai bukti bagi tenaga yang berwenang. Dokumentasi keperawatan yang berlaku di rumah sakit saat ini umumnya dilakukan secara tertulis (paper based documentation).Pendokumentasian asuhan keperawatan merupakan hal yang sangat penting bagi perawat professional oleh karena dalam melaksanakan asuhan keperawatan, perawat harus membuat suatu rencana dan digunakan sebagai bukti yang dapat dipertanggungjawabkan.

komunikasi antar petugas kesehatan dalam rangka pemulihan kesehatan klien. Perawat bertanggung jawab dan bertanggung gugat dalam pencatatan tindakan keperawatan. Tanpa dokumentasi yang benar dan jelas, kegiatan pelayanan keperawatan yang telah dilaksanakan oleh seorang perawat tidak dapat dipertanggungjawabkan dalam upaya peningkatan mutu pelayanan keperawatan dan perbaikan status kesehatan klien. Pendokumentasian asuhan keperawatan tidak lengkap disebabkan beberapa hal. Menurut Bergh, Bergh, dan Friberg (2007), pen-dokumentasian tidak memadai disebabkan oleh tidak sinkronnya proses keperawatan yang didokumentasikan.

Tanpa dokumentasi yang benar dan jelas, kegiatan pelayanan keperawatan yang telah dilaksanakan oleh seorang perawat tidak dapat dipertanggungjawabkan dalam upaya peningkatan mutu pelayanan keperawatan dan perbaikan status kesehatan klien. Dokumentasi keperawatan merupakan suatu yang mutlak harus ada untuk perkembangan keperawatan khususnya proses profesionalisasi keperawatan serta mempertahankan keperawatan sebagai suatu profesi yang luhur dan terpandang di masyarakat. Dokumentasi keperawatan adalah bagian dari keseluruhan tanggung jawab perawatan pasien. Catatan klinis memfasilitasi pemberian perawatan, meningkatkan kontinuitas perawatan dan membantu mengkoordinasikan pengobatan dan evaluasi pasien 


\section{Keuntungan dan Kelemahan Metode Dokumentasi}

\section{a. Paper Based Documentation}

Metode ini di lakukan secara tertulis mempunyai kelemahana yaitu memerlukan waktu yang cukup lama untuk mengisi form yang tersedia, membutuhkam biaya percetakan form yang cukup mahal, sering hilang atau terselip, memerlukan tempat penyimpanan yang luas dan menyulitkan pencarian kembali saat diperlukan. Metode ini juga memiliki keuntungan dalam penahanan lainnya meliputi: keinginan untuk terus menggunakan dokumentasi berbasis kertas, kurangnya pengalaman komputer, dan sikap negatif terhadap computer.

\section{b. Elektronik}

Dokumentasi keperawatan berbasis elektronik ini memberikan keuntungan bagi perawat dalam hal waktu pendokumentasian yang lebih singkat, keterbacaan data dan kemudahan akses bila dibandingkan dokumentasi dalam format kertas. Pengembangan dokumentasi keperawatan berbasis elektronik tetap harus memperhatikan prinsip kerahasiaan data klien, komprehensif, akurat, tepat waktu, dan jelas mengidentifikasi pemberi perawatan sehingga perlu adanya kebijakan dan pedoman yang jelas bagi tenaga perawat dalam menjalankan sistem ini. Kelemahan ataupun Kendala dalam metode ini adalah loading lama, loading error, dan tidak ada sinyal.

Pendokumentasian elektronik merupakan sistem pencatatan berbasis komputer yeng merekam aktifitas yang dilakukan oleh perawat dalam aktivitas keperawatan, yaitu pendokumentasian asuhan keperawatan. Catatan yang ditulis menginformasikan semua kunjungan perawat dalam bentuk catatan ringkasan singkat dari kebutuhan perawatan pasien dan intervensi yang telah diterapkan.

\section{Model Dokumentasi Problem Oriented Record ( POR )}

Beberapa model asuhan keperawatan yang ada, Model pemberian asuhan keperawatan perlu disesuaikan dengan kondisi dan kebutuhan pasien yang sampai saat ini terdiri dari enam model yang meliputi SOR (Source-Oriented Record), POR (Problem Oriented Record), Progress Notes, CBE (Charting By Exception), PIE (Problems Intervention and Evaluation), Focus (Process Oriented System) salah satunya adalah model keperawatan Problem Oriented Record (POR). 
Pendokumentasian keperawatan menggunakan model POR mempunyai keuntungan yang dikemukakan oleh Damayanti (2010), bahwa penggunaan model POR mempunyai metode logis untuk melakukan analisis dan pemecahan masalah, memungkinkan komunikasi yang lebih efektif, terdiri atas pembahasan singkat tentang setiap masalah yang ada dalam daftar masalah dan bagaimana masalah tersebut berakhir, apakah berhasil atau tidak berhasil diselesaikan. Model Pendokumentasian keperawatan menggunakan model problem oriented record (POR) lebih mudah diterapkan karena model ini memusatkan data tentang klien dan didokumentasikan dan disusun menurut masalah klien. Sistem dokumentasi jenis ini mengintegrasikan semua data mengenai masalah yang dikumpulkan oleh dokter, perawat atau tenaga kesehatan lain yang terlibat dalam pemberian layanan kepada klien

Model Pendokumentasian keperawatan menggunakan model problem oriented record (POR) lebih mudah diterapkan karena model ini memusatkan data tentang klien dan didokumentasikan dan disusun menurut masalah klien. Sistem dokumentasi jenis ini mengintegrasikan semua data mengenai masalah yang dikumpulkan oleh dokter, perawat atau tenaga kesehatan lain yang terlibat dalam pemberian layanan kepada klien. Model keperawatan ini banyak digunakan di negara-negara lain karena berorientasi pada masalah pasien, dapat menggunakan multi disiplin dengan mengaplikasikan pendekatan pemecahan masalah. Model POR ini mengintegrasikan semua masalah yang dikumpulkan oleh dokter, perawatatau tenaga kesehatan yang lain yang terlibat dalam pemberian layanan kepada pasien. Model POR ini mengintegrasikan semua masalah yang dikumpulkan oleh dokter, perawatatau tenaga kesehatan yang lain yang terlibat dalam pemberian layanan kepada pasien.

\section{PENUTUP}

\subsection{Kesimpulan}

Dalam tujuan dokumentasi keperawatan termasuk penelitian tentang perawatan yang lebih efektif dari masalah yang sudah terdeteksi, pemrograman perawatan melalui organisasi dan modifikasi rencana perawatan pasien dan komunikasi yang lebih langsung antara para profesional dari sistem kesehatan, yang berkolaborasi dalam perawatan pasien. Metode dokumentasi banyak dan di antara yang paling mendasar adalah metode yang diarahkan pada sumber atau masalah, sistem masalah-intervensievaluasi, registrasi terfokus, diagram fokus, registrasi dengan pengecualian, file elektronik dan rumah dokumentasi. Dokumentasi 
keperawatan yang berlaku di rumah sakit saat ini umumnya dilakukan secara tertulis (paper based documentation). Metode ini mempunyai kelemahan yaitu memerlukan waktu yang cukup lama untuk mengisi form yang tersedia, membutuhkam biaya percetakan form yang cukup mahal, sering hilang atau terselip, memerlukan tempat penyimpanan yang luas dan menyulitkan pencarian kembali saat diperlukan. Dokumentasi keperawatan berbasis elektronik ini memberikan keuntungan bagi perawat dalam hal waktu pendokumentasian yang lebih singkat, keterbacaan data dan kemudahan akses bila dibandingkan dokumentasi dalam format kertas.

\section{DAFTAR PUSTAKA}

Ardenny dan Hirzal. 2016. Efektivitas format pendokumentasian keperawatan model problem oriented record ( POR ) terhadap kemudahan penggunaanya oleh perawat di rawat inap jalan RSUD petala bumi pekanbaru. Pekanbaru : Volume VIII, No. 3

Astuti, neneng, dkk. 2010. Analisis kelengkapan pendokumentasian asuhan keperawatan pasien di rawat inaprumah sakit tampan pekan baru. Pekanbaru : Vol. 1 No.1, Oktober 2010

Aziz, Alimul. Pengantar Dokumentasi Proses Keperawatan. Jakarta: EGC.2009

Gustomi, Mono Pratiko dan Churin'in. 2015. Penerapan model dokumentasi asuhan keperawatan Problem Oriented Record (POR) Terhadap kinerja perawat (Effect of Problem Oriented Record (POR) Nursing Documentation Model on the Performance of Nurses).

Gersik : Volume 06, Nomor 02, November 2015

Huda, Amin, dkk. 2015. Aplikasi Asuhan Keperawatan Berdasarakan Diagonosa Medis \& Nanda Nic-Noc, Edisi : 3. Jogjakarta : MediAction

Hutahaen, Serii. (2010). Konsep dan Dokumentasi Proses Keperawatan. Jakarta: Info Media Jakarta

Nursalam, 2008, Proses dan Dokumentasi Keperawatan : Konsep danPraktik, SalembaMedika, Jakarta.

Simamora, R. (2009). Dokumentasi Proses Keperawatan. 
Simamora, R. H., Purba, J. M., Bukit, E. K., \& Nurbaiti, N. (2019). Penguatan Peran Perawat Dalam Pelaksanaan Asuhan Keperawatan Melalui Pelatihan Layanan Prima. JPPM (Jurnal Pengabdian Dan Pemberdayaan Masyarakat), 3(1), 25-3

Siswanto, Harmain L.M ,dkk. 2013. Faktor factor yang berhubungan dengan kelebgkapan pendokumentasian asuhan keperawatan. Vol. 16, no. 2

Sugiyati, Sri. 2015. Hubungan Pengetahuan Perawat Dalam Dokumentasi Keperawatan Dsengan Pelaksananya Di Rawat Inap RSI Kendal. Kendal : Vol. 8 No. 2 Oktober 2015 : 109 $-125$

Sulatri. Dan niken yuniar sari. 2018. Metode pendokumentasian elektronik dalam meningkatkan kualitas pelayanan keperawatan. Volume 9, no. 3

Wulandari. Dyah fitri dan Hanny Handiyani. Pengembangan dokumentasi Keperawatan berbasis elektronik di rs x kota depok dengan menggunakan teori perubahan lewins. Jurnal Keperawatan Global, Vol. 4 , No. 1,Juni 2019 